DOI https://doi.org/10.30525/978-9934-26-079-7-18

\title{
ФІЛОСОФСЬКІ ПРОБЛЕМИ БЕЗПЕРЕРВНОЇ МИСТЕЦЬКОЇ ОСВІТИ
}

\author{
Дяченко А. В. \\ кандидат педагогічних наук, \\ дочент кафедри промислового дизайну і комп'ютерних технологій \\ Київської державної академії декоративно-прикладного мистеитвва \\ і дизайну імені Михайла Бойчука \\ м. Київ, Украӥна
}

У період зміни освітньої парадигми особливої актуальності набувають питання, пов'язані з трактуванням поняття «освічена людина», із засобами і способами ii формування, з розвитком і реалізацією іiі здібностей протягом усього життя, зі створенням умов, необхідних для цього. Об'єктивне взаємопроникнення в кінці 20 століття двох історично сформованих моделей освіти (природозгідним і культуро-згідним) дозволило трактувати безперервну освіту як особистісний та професійний розвиток людини в культурному контексті.

Дана домінуюча ідея співзвучна функціональним можливостям мистецтва, яке, будучи унікальним явищем людського буття, виражається в художній творчості, має силу в правді і красі і сприяє формуванню в людині культури сприйняття навколишнього світу. Про це, перш за все, свідчать багаті традиції розвитку вітчизняної культури і художньої освіти.

Безперервність $є$ закономірністю і імперативом художньої освіти, так як пов'язана 3 діалектичною природою самого мистецтва, 3 психологічними особливостями розвитку особистості [1, с. 112 ], 3 професійним становленням фахівців в області мистецтва або художньо-педагогічної освіти.

На основі вивчення історії, теорії та практики художньої освіти можна, по-перше, стверджувати, що ії безперервність з метою формування цілісного світогляду молоді $є$ настійною вимогою часу, i, подруге, розглядати безперервну художню освіту як процес розвитку протягом усього життя загальнокультурного та професійного потенціалу людини, механізм культурного розвитку суспільства і систему, що забезпечує для цього необхідні умови.

Неперервна художня освіта виконує нічим незамінну роль в збереженні і розвитку національних культурних традицій, в процесі етнічної самоідентифікації та інтеграції особистості в духовну культуру: національну та світову. Відкриваючи двері в інший світ культури, 
мистецтво вчить розумінню i прийняттю іншої людини, сприяє становленню толерантної свідомості, гуманістичної спрямованості особистості.

$\epsilon$ діалектикою взаємообумовлених сторін: художньої культури суб'єкта, художньої культури суспільства і художньо-освітньої системи. Перші дві з них піддаються впливам в культурному контексті, часто стихійним. Третя ж (художньо-освітня система) надає даному процесу педагогічну спрямованість.

Можна сказати, що цілісна панорама системи неперервної мистецької освіти охоплює три соціально-вікових періоди: допрофесійну підготовку, період професійної підготовки, період професійного вдосконалення і загальнокультурного розвитку. Кожен з цих періодів розглядається як з точки зору загальної, так і спеціальної художньої освіти.

Доцільна інтеграція можливостей мистецтва і педагогіки в освітньому процесі здатна створювати сприятливі умови для виходу на інше, якісно нове сприйняття, уявлення, розуміння сенсу навчальновиховного змісту, оскільки арт-педагогічні засоби можуть:

- бути рівноправним джерелом навчальної інформації, своєрідним «голосом» в навчальному діалозі, що розповідає про суб'єктивні стани, тонкі нюанси емоційного руху, душевних переживань іншої людини;

- забезпечувати особистісно-суб'єктивоване переживання («проживання») навчально-виховного змісту, актуалізацію і виявлення особистісних смислів;

- бути джерелом автентичної інформації, на основі якої можливе створення емоційного або історико-культурного контексту досліджуваного навчального матеріалу (своєрідна «перекличка» часів, емоційних станів, характерів, людських індивідуальностей);

- створювати поле найрізноманітніших асоціацій, відчуттів, думок, забезпечуючи тим самим режим інформаційного доповнення, збагачення навчально-виховного змісту індивідуальним (унікальним) досвідом учасників;

- сприяти трансформації вихідних установок, позицій, звичних ракурсів сприйняття і оцінки;

- стати джерелом самопізнання, самовираження, ціннісносмислового збагачення «Я»-концепції.

Треба відзначити, що якщо раціональне виділилося і лідирує в сучасному світі, то ірраціональне фактично вилучено зі сфери науки і тим більше з освіти [3]. Неперервна художня освіта виконує нічим незамінну роль в збереженні і розвитку національних культурних традицій, в процесі етнічної самоідентифікації та інтеграції особистості в духовну культуру: національну та світову. Відкриваючи двері в інший світ культури, мистецтво вчить розумінню і прийняттю іншої людини, 
сприяє становленню толерантної свідомості, гуманістичної спрямованості особистості.

Неперервна мистецька освіта повинна базуватися на націокультурній традиції, надбаннях української педагогіки, досвіду поколінь у широкому розумінні. Вона повинна відтворювати менталітет нації, відповідати характеру української людини та відтворювати їі світовідчуття.

Розглядаючи мистецьку освіту з позиції філософії ,можна виділити низку завдань, які вимагають першочергового вирішення. До них належать:

- переосмислення світоглядних основ гуманістичного пізнання;

- забезпечення гуманістичної спадкоємності у мистецькій освіті, піднявши їі ефективність на всіх етапах і особливо на завершальному етапі - в галузі вищої мистецької освіти;

- впровадження різних навчальних програм, спрямованих на вивчення здобутків своєї національної культури та культур інших народів світу з пріоритетом духовних і моральних цінностей [2].

Навчання протягом усього життя - це три типи освіти і навчання: формальне навчання (ВН3, інші навчальні структури, які видають свідоцтво про освіту); спонтанне навчання (під час повсякденної життєдіяльності людини, пов'язаної з їі роботою, сім'єю або дозвіллям), неформальне навчання (поза рамками навчального закладу) [ 4]. Одним 3 перспективних напрямків в мистецькій освіті може стати створення нетрадиційних навчальних закладів: «університетів без стін», «шкіл гнучкого навчання» [5] і т. п. Тим самим буде відбуватися стирання кордонів між різними стадіями освітнього процесу, і відповідно, забезпечуватися безперервність впливу на формування світогляду молодих людей.

\section{Література:}

1. Бех, І. Д. Духовні цінності в розвитку особистості .Педагогіка і психологія. 1997. № 1. 112-117 с.

2. Кузнецова А.Я. Функциональные основания современной философии образования . Современные наукоемкие технологии. 2010. № 8. 85-86 c.

3. Скотний В.Г. Філософія освіти: екзистенція ірраціонального в раціональному: монографія . Дрогобич: Вимір, 2004. 348 с.

4. Bhatia P. Lifelong learning - learning to learn. The Business \& Management Review, Volume 5 Number 4, 2015. 265-268 pp.

5. Bull, S. \& Kay, J. Open Learner Models. In: R. Nkambou, J. Bordeau \& R. Miziguchi (Eds.), Advances in Intelligent Tutoring Systems, Springer, 2010. 318-338 pp. 